\begin{tabular}{|l|l|r|}
\hline A1 Fitrah & \\
Journal Of Early Childhood Islamic Education & Strategy Of Early Childhood Learning Model \\
ISSN $:$ 2599-2287 & Development \\
Khairiah \\
Vol.1 No.2 Januari 2018
\end{tabular}

\title{
STRATEGY OF EARLY CHILDHOOD LEARNING MODEL DEVELOPMENT
}

\begin{abstract}
Abstrak
This paper will discuss about the strategy of developing early childhood learning model. This discourse is very important to be studied in view of the development of dynamic times and curricula. Recent discoveries in the field of education require educators to innovate in producing superior educational products including early childhood education. To achieve the goal of science learning in early childhood optimally, the PAUD organizers should consider the model, approach and strategy that will be applied. And improve the process skills that must be owned by early childhood. In order to learn science is not considered as difficult and boring by early childhood.
\end{abstract}

Keywords : Strategy, Early Childhood, Development

\section{Background}

Early childhood education and learning development is very important. Science education should be immediate and must be given to every child at an early age. During this early childhood mistaken for having viewed science as a lesson that is difficult and boring. The early childhood error must be stopped and the solution is sought. Science teachers and educators should enhance their ability to introduce science to children, both in discerning and discovery content, in reviewing and disclosing the process of science (utilization of process), as well as in attaching scientific attitudes (scientist personality) so as to lead the child to a true understanding of science and its scope.

The Journal entitled Development of Science Learning Model for MI / SD Students (Murtono, 130) explains that the learning model is a learning pattern that can explain the process, mention and produce a certain learning environment so that learners can interact which in turn leads to changes in the students' special.

There are several models of learning program development or curriculum that can be used as guidance in the development of science learning program in early childhood. Tytler in Samatowa (2010: 57) states that each model has phases with different terms, but basically has the same purpose, namely: 


\begin{tabular}{|c|c|c|}
\hline$\sqrt{5}$ & $\begin{array}{l}\text { Al Fitrah } \\
\text { Journal Of Early Childhood Islamic Education } \\
\text { ISSN : 2599-2287 } \\
\text { Vol.1 No.2 Januari } 2018\end{array}$ & $\begin{array}{r}\text { Strategy Of Early Childhood Learning Model } \\
\text { Development } \\
\text { Khairiah }\end{array}$ \\
\hline
\end{tabular}

- Dig out student ideas

- Conduct clarification and extension of the idea

- Reflect it explicitly.

According to the constructivist view in Samatowa (2012: 63) in the learning process of science should be provided a series of experience in the form of real activities that are rational or understandable and enable students to occur social interaction. In other words when the learning process takes place the students must be directly involved with the real activities.

\section{Literature Review}

From the point of language, science comes from the Latin, that is from word scientia means knowledge. Experts view the etymological restrictions of science from German, it refers to the word Wissenschaft, which has a systematically organized or organized understanding of knowledge.

Some experts who propose a number of understanding and limitations of science are:

1. Amien (1987), defines science as the field of natural science, with the scope of matter and energy, both living and non-living, discussing more about nature such as physics, chemistry and biology.

2. James Conant (Holton and Roller: 1958), science as a sequence of concepts and conceptual schemes related to each other, growing as a result of a series of experiments and observations and can be observed and tested further.

3. Conant (Abu Ahmadi, 1991), science as a theoretical science based on observation, experiments on natural phenomena of the macrocosm (the universe) and microcosm (the more limited content of the universe, especially of man and his properties).

4. Fisher (1975), science as a collection of knowledge gained by using methods based on observation with full research.

Analytically, some scholars try to limit the science by dividing science by the dimension of the study. Sumaji (1988), that narrowly science is a science of nature (IPA) consisting of physcal science (astronomy, chemistry, geogology, chemistry, physics) and life science (biology, zoology, and physiology).

- Ernest Hagel (Indrawati, 1995), views science from three aspects: 


\begin{tabular}{|c|c|c|}
\hline$\stackrel{5}{a}$ & $\begin{array}{l}\text { Al Fitrah } \\
\text { Journal Of Early Childhood Islamic Education } \\
\text { ISSN : 2599-2287 } \\
\text { Vol.1 No.2 Januari } 2018\end{array}$ & $\begin{array}{r}\text { Strategy Of Early Childhood Learning Model } \\
\text { Development } \\
\text { Khairiah }\end{array}$ \\
\hline
\end{tabular}

The aspect of science

an idea that is a generalization objectives is as a tool for control of nature and to contribute to human welfare.

- Science as a systematic and tough knowledge in the sense of a result or conclusion derived from various events.

- Science as a method, which is a set of rules to solve problems, to get or know the cause of an event and to get the laws or theories of the object being observed.

Some descriptions of the boundaries of science:

- As a process is a method to gain knowledge

The description of science is closely related to the symptom search activity and natural factors undertaken through laboratory activities. Science is viewed as a strict discipline based on activity, observation, hypothesis (conjecture).

- Science as a product consists of facts, concepts of principle, law and theory. Fact is something that has or is happening that can be a state,

The limits of science are viewed from the child's point of view, according to Carson, 1965 (Holt, 1991) based on his observations of children's behavior when with various objects of science, he concludes that science for children is all that is amazing, something found and considered interesting and give knowledge or stimulate it to know and investigate.

- With these limits, children's science can be found all over the place, both at home, at home, at school and beyond. Examples of concrete more real, for example : 


\begin{tabular}{|c|c|c|}
\hline$\Leftrightarrow$ & $\begin{array}{l}\text { A1 Fitrah } \\
\text { Journal Of Early Childhood Islamic Education } \\
\text { ISSN : 2599-2287 } \\
\text { Vol.1 No.2 Januari } 2018\end{array}$ & $\begin{array}{r}\text { Strategy Of Early Childhood Learning Model } \\
\text { Development } \\
\text { Khairiah }\end{array}$ \\
\hline
\end{tabular}

The child catches a dragonfly, inserts it into a topies, observes it and feels it, next arises pity (pity) so that the feeling grows better to be released.

- Children wear jackets in winter (cold) and feel them warm during and after wearing them.

Development of science learning for children effectively and optimally should melalyu ways that can unite science, we and children in a center or a synergistic and harmonious activities.

The importance of goals in science learning has every area of instructional development in early childhood education, a goal that is considered standardized and chooses the ideal characteristics, if the objectives formulated select the level of accuracy (validity), meaning (meaning fulness), functional and high relevance with needs and target characteristics.

Science as one means of exposing the existence and secrets of the universe and its contents or as one means of achieving the goal of human life is very important to be understood and mastered.

\section{Discussion}

Abruscato (1982) considers that school activities that are often spent to sharpen the mind and absorb knowledge simply are wrong. Referring to the theory of cognitive development, most importantly the child absorbs as much knowledge, but how the child can remember and precipitate it, and how he can use the kosnep and the principles he learns in his life or learning. So the true value of cognitive developmental properties should lead to two dimensions, namely the dimensions of the content and the dimensions of the process. In directing the child to encompass the content of knowledge, done through meaningful processes or activities. If the child is expected to master the concepts related to science both the fact of concept and theory. Facilitate them in mastering through activities that may include both content and process dimensions, eg through observation, reading, discussion, experiments or relevant media.

Every child from an early age needs to be given and is involved in an atmosphere or situation that can give an imprint. Affective players will stick and become a character that personally or individualizes the child's identity. If the development is tailored to the behavioral demands that occur significantly in the child's life. So the value of the developed affection is a pattern of behavior that is actually manifested in deeds. Teachers' duty in 


\begin{tabular}{|c|c|c|}
\hline int & $\begin{array}{l}\text { Al Fitrah } \\
\text { Journal Of Early Childhood Islamic Education } \\
\text { ISSN : 2599-2287 } \\
\text { Vol.1 No.2 Januari } 2018\end{array}$ & $\begin{array}{r}\text { Strategy Of Early Childhood Learning Model } \\
\text { Development } \\
\text { Khairiah }\end{array}$ \\
\hline
\end{tabular}

science learning is to provide a learning environment that is fun, meaningful, touching children so as to foster positive child affection.

Aiming at the demands of the child has the ability to move the limbs and their parts. Development of science with attached properties can help improve the psychomotor skills of children. Rough motoric children can develop through competitiveness. For example by forming buildings from sand, soil, farming flowers, and others. While fine motor is done through the activity of line with pencil and ruler, measure, sorting objects (rough, smooth and others) cutting and so on. Thus, motor development will be much obtained mellui science activities that are cognitive and affective value, meaning that motor activity will contribute positively to the cognitive and affective formation of children in the recognition and mastery of science.

Through the development of science in children will invite and cultivate a very high curiosity. Setting and the science learning environment provided will stimulate the child to come up with amazing questions. Then that is the manifestation of real creative thinking and learning. The value of science for the development and growth of children is the power of thought and imagination of children in asking a question or by inviting children to observe a plant growth growth then the child's critical thinking skills will develop.

If science-learning development practices are given in such a way, maturity in aspects of development in the child will be even better if the accumulation of the impacts of science learning continues to grow, will contribute positively to improving the child's ability to actualize himself in a wide life.

Sumaji (1980) recognizes the more widespread and in a person studying science, he will feel smaller as a being compared to God. That is the other value of science, it turns out that understanding of science correlates with the increased awareness of one's religious values. Issac Newton for example, a leading physicist likes himself as a child who is playing shells on the beach. While the oceans are stretched like science.

Like Wilardja (1997) states with the development process of learning the right saiins in children, then the child will be accustomed to be an honest figure and not easily prejudiced to be a persistent and diligent person in the face of difficulties, even able to grow the religious value, the sense of gratitude and glorification. 


\begin{tabular}{|c|c|c|}
\hline$\Leftrightarrow$ & $\begin{array}{l}\text { A1 Fitrah } \\
\text { Journal Of Early Childhood Islamic Education } \\
\text { ISSN : 2599-2287 } \\
\text { Vol.1 No.2 Januari } 2018\end{array}$ & $\begin{array}{r}\text { Strategy Of Early Childhood Learning Model } \\
\text { Development } \\
\text { Khairiah }\end{array}$ \\
\hline
\end{tabular}

Of the many science activities developed for children, namely cognitive, affective, and psychomotor skills as well as critical thinking and creativity, actuality and religious values of children. A teacher should be able to provide a fun science activities, from the activity the way children think and imagine and the child's curiosity will be more aroused. And the curiosity of what, why, will be missed from such activities as well as the affective and psychomotor development of the child also evolves in line with cognitive development.

The cognitive development of the thinking power of the child, the affective development of the child's behavior and the psychomotor's development of fine motor and fine motor. For example forming wake up from sand (gross motor), forming with playdought / platisin (fine motor).

By taking a child out of the school or going to the beach. Explain to the children that it is God's creation, and man is also God's creation, so that the child knows who the creator is and that the child also has a sense of gratitude and low selfesteem. That is the religious value developed in children and the way children think critically of the creation of this universe.

\section{Conclusion}

Development of learning program is generally the scope of science learning for early childhood that includes 2 dimensions that is seen from the content of the study materials and views of the field of development capabilities to be achieved.

This model of early science learning programs for early childhood is a sciencelearning model that requires early childhood to engage directly with real-life activities while the learning process is in progress. Approaches and strategies chosen with consideration can present and provide adequate and integrated science activities in children. Skills of the science process that must be taught and trained in early childhood are observing, grouping, interpreting, predicting, applying, planning research, and communicating.

\section{References}

Murtono, "Pengembangan Model Pembelajaran Sains Bagi Siswa MI/SD”, Jurnal, (Yogyakarta: UIN Sunan Kalijaga) Novitahadsari, "Peningkatan Keterampilan Mengkomunikasikan Sains Melalui Media 


\begin{tabular}{|l|l|r|}
\hline A1 Fitrah & Strategy Of Early Childhood Learning Model \\
Journal Of Early Childhood Islamic Education & Development \\
ISSN : 2599-2287 & Khairiah \\
\hline & Vol.1 No.2 Januari 2018 & \\
\hline
\end{tabular}

Grafis Pada Anak Kelompok B TK ABA

Balerante Sleman Yogyakarta”, Skripsi,

(Yogyakarta: UNY, 2014)

Nugraha,

Ali. 2005.

PengembanganPembelajaran Sains Pada

Anak Usia Dini. Jakarta: Departemen
Pendidikan

Nasional

Samatowa, Usman. 2010. Pembelajaran Ipa di Sekolah Dasar. Jakarta: PT Indeks Yulianti, Dwi. 2010. Bermain Sambil Belajar Sains di Taman Kanak - Kanak. Jakarta: PT Indeks 